\title{
Perbandingan Konsep Keuangan pada Bank Syariah dan Bank Konvensional
}

\section{Comparison of Financial Concepts in Islamic Banks and Conventional Banks Miftahuddin*}

\author{
Program Studi Ilmu Manajemen, Fakultas Ekonomi dan Bisnis, \\ Universitas Medan Area, Indonesia
}

Diterima: Agustus 2019; Disetujui: Desember 2019; Dipublish: Desember 2019

*Coresponding Email: miftahuddin@staff.uma.ac.id

\begin{abstract}
Abstrak
Makalah ini mencoba untuk meninjau perbandingan Bank Syariah dan Konvensional di Indonesia. Ada 11 sub-topik yang membahas tentang konsep dan hal-hal yang terkait dengan kedua jenis Bank. Ini termasuk elaborasi tentang prinsip, produk, institusi, nilai waktu uang, dan bunga versus pembagian keuntungan. Untuk setiap prinsip, itu berasal dari Al-Qur'an dan Hadits. Semua penjelasan adalah poin penting yang terkait dengan sistem bank syariah. Dengan contoh-contoh dan simulasi nyata dalam perhitungan yang disajikan dalam artikel ini, setiap produk dapat dipahami secara komprehensif oleh pembaca. Konsep perbankan Islam ini mengungkapkan nilai-nilai, norma-norma, dan aspek etika seperti keadilan, keadilan, trusworthy untuk kreditor dan debitor yang juga membawa kebaikan atau maslahah kepada masyarakat. Diharapkan bahwa bank syariah dapat memberikan layanan yang sangat baik dan bersaing secara internasional. Dengan semua dukungan dari para pemangku kepentingan, pengembangan dan pertumbuhan bank syariah dapat dicapai.
\end{abstract}

Kata kunci: Bank Islam, Bank Konvensional, Riba, Nilai dan Prinsip Islam, Indonesia.

\begin{abstract}
This paper attempts to review the comparison of the Islamic and Conventional Banks in Indonesia. There are 11 sub-topics which discuss on the concepts and matters related to both type of Banks. This include the elaboration about principles, products, institutions, time value of money, and interest versus profitsharing. For each principles, it derived from the Al-Qur'an and Hadith. All explanations are the important points associated with the Islamic banks systems. With the examples and real simulation in calculations which presented in this article, each products can be understood comprehensively by the readers. This Islamic banking concept reveals the values, norms, and ethical aspects such as justice, fairness, trusworthy for the creditors and debitors that also bring goodness or maslahah to the society. It is expected that Islamic banks could deliver excellent services and compete internationally. With all the supports from stakeholders, the development and growth of Islamic banks is achievable.
\end{abstract}

Keywords: Islamic Banks, Conventional Banks, Riba, Islamic Values and Principles, Indonesia.

How to Cite: Miftahuddin. (2019). Perbandingan Konsep Keuangan pada Bank Syariah dan Bank Konvensional. Journal of Education, Humaniora and Social Sciences (JEHSS). 2 (2): 213-228. 


\section{PENDAHULUAN}

Dana Moneter Internasional (IMF) merilis laporan yang menyatakan bahwa perbankan Islam adalah salah satu segmen pertumbuhan tercepat di industri keuangan dengan pertumbuhan 10-15 persen selama dekade terakhir, dan secara global, aset perbankan syariah diperkirakan tumbuh sekitar 15 persen per tahun dari \$1 triliun pada tahun 2016 (https://www.imf.org/external/pubs/ft/ar/2016/eng/pdf/ar16 eng.pdf). Ini adalah indikator bahwa perbankan Islam mulai dilirik akan peranannya kepada keuangan global secara keseluruhan.

Kehadiran bank berdasarkan syariah di Indonesia masih relatif baru, yaitu tahun 1990-an, meskipun masyarakat Indonesia mayoritas adalah beragama Islam atau Muslim. Diskusi tentang bank syariah sebagai basis ekonomi Islam sudah dimulai pada awal tahun 1980 tetapi prakarsa untuk mendirikan bank syariah pertama di Indonesia dilakukan oleh Majelis Ulama Indonesia (MUI) pada tanggal 18-20 Agustus 1990.

Bank syariah pertama di Indonesia merupakan hasil kerja tim perbankan MUI, yaitu dengan dibentuknya PT. Bank Muamalat Indonesia (BMI) yang akte pendiriannya di tanda tangani 1 November 1991 (Antonio, 2016). BMI tetap menjadi satu-satunya bank syariah komersil (BUS) sampai terjadinya krisis keuangan pada tahun 1997 yang mengakibatkaan kerusakan yang masif pada system keuangan di Indonesia.

Dalam perkembangan selanjutnya kehadiran bank syariah di Indonesia cukup mengembirakan dan tumbuh baik di perbankan syariah BUMN maupun bank syariah swasta, yang beroperasi hampir seluruh provinsi, kabupaten dan kota. Selain bank BMI, saat ini juga lahir bank syariah milik pemerintah seperti Bank Syariah Mandiri (BSM), Bank Negara Indonesia (BNI) Syariah, BRI Syariah, Bank Jabar Banten Syariah dan Bank Syariah Swasta lainnya seperti Bank Panin Syariah, Banak Maybank Syariah Indonesia, Bank Syariah Mega, Bank Bukopin Syariah dan lain-lain. Kehadiran bank syariah ternyata tidak dilakukan oleh hanya masyarakat Muslim, tetapi juga bank milik non-muslim. Saat ini perbankan Islam sudah tersebar di beberapa negara Muslim dan Non Muslim (Kasmir, 2010). Sebagai contoh, jumlah bank pembiayaan rakyat syariah meningkat secara signifikan dari 105 pada tahun 2006 menjadi 165 pada tahun 2019 dan saat ini, terdapat 2.746 kantor cabang perbankan syariah di Indonesia. Berikut indikator utama perbakan syariah di Indonesia di bawah ini: 
Tabel 1. Indikator Utama Perbankan Syariah

\begin{tabular}{|l|l|l|l|l|l|}
\hline Industri Perbankan & $\begin{array}{l}\text { Jumlah } \\
\text { Institusi }\end{array}$ & $\begin{array}{l}\text { Jumlah } \\
\text { Kantor }\end{array}$ & $\begin{array}{l}\text { Aset (dalam } \\
\text { triliun rupiah) }\end{array}$ & $\begin{array}{l}\text { PYD* (dalam } \\
\text { triliun rupiah) }\end{array}$ & $\begin{array}{l}\text { DPK** (dalam } \\
\text { triliun rupiah }\end{array}$ \\
\hline Bank Umum Syariah & 14 & 1.886 & 318,06 & 205,92 & 262,71 \\
\hline Unit Usaha Syariah & 20 & 364 & 161,76 & 121,07 & 120,02 \\
\hline $\begin{array}{l}\text { Bank Pembiayaan } \\
\text { Rakyat Syariah }\end{array}$ & 165 & 496 & 12,41 & 9,40 & 8,14 \\
\hline TOTAL & 199 & 2.746 & 492,23 & 336,39 & 390,87 \\
\hline
\end{tabular}

* Pembiayaan yang disalurkan

**Dana Pihak Ketiga

Sumber: OJK

Pengembangan sistem perbankan syariah di Indonesia dilakukan dalam kerangka dual-banking system atau sistem perbankan ganda dalam kerangka Arsitektur Perbankan Indonesia (API), untuk menghadirkan alternatif jasa perbankan yang semakin lengkap kepada masyarakat Indonesia. Secara bersama-sama, sistem perbankan syariah dan perbankan konvensional dengan sinergis mendukung mobilisasi dana masyarakat secara lebih luas untuk meningkatkan kemampuan pembiayaan bagi sektor-sektor perekenomian nasional.

Bank syariah adalah bank melaksanakan kegiatan usaha berdasarkan prinsip syariah, yaitu aturan perjanjian berdasarkan hukum Islam antara bank dan pihak lain untuk penyimpanan dana dan/atau pembiayaan kegiatan usaha, atau kegiatan lainnya yang dinyatakan sesuai dengan syariah. Dalam menjalankan usahanya bank syariah menggunakan pola bagi hasil (profit and sharing) yang merupakan landasan utama dalam segala operasinya, baik dalam produk pendanaan, pembiayaan maupun dalam produk lainnya. Produk-produk bank syariah mempunyai kemiripan tetapi tidak sama dengan produk bank konvensional karena adanya pelarangan seperti maysir, gharar, riba, haram, riswah (suap) dan yang bathil. Oleh karena itu, produk-produk pendanaan dan pembiayaan pada bank syariah harus menghindari dari unsur-unsur yang dilarang tersebut (Ascarya, 2012).

Dilihat dari cara menentukan harga bank konvensional dan bank syariah mempunyai perbedaan. Perbedaan tersebut dalam penentuan harga baik untuk harga jual maupun harga beli. Dalam bank konvensional penetuan harga selalu di dasarkan kepada bunga sedangkan pada bank syariah didasarkan kepada konsep Islam, yaitu kerja sama dalam skema bagi hasil, baik untung maupun rugi (Kasmir, 2010).

Sebagai lembaga intermediasi, bank konvensional menerima simpanan dari nasabah dan meminjamkannya kepada nasabah (unit ekonomi) lain yang membutuhkan dana. Atas simpanan para nasabah itu bank memberi imbalan bunga. Demikian pula, atas 
pemberian pinjaman itu bank mengenakan bunga kepada para peminjam. Diakui bahwa peran bank konvensional itu telah mampu memenuhi kebutuhan manusia, dan aktivitas perbankan dapat dipandang sebagai wahana bagi masyarakat modern untuk membawa mereka kepada pelaksanaan kegiatan tolong-menolong dan menghindari adanya danadana yang menganggur (idle).

Dalam operasional perbankan konvensional terdapat kegiatan-kegiatan yang dilarang syariah Islam, seperti menerima dan membayar bunga (riba), membiayai kegiatan produksi dan perdagangan barang-barang yang dilarang syariah seperti minuman keras (Mufti dan Sula, 2009). Karateristik sistem perbankan syariah yang beroperasi berdasarkan prinsip bagi hasil memberikan alternatif sistem perbankan yang saling menguntungkan bagi masyarakat dan bank, serta menonjolkan aspek keadilan dalam bertransaksi, investasi yang beretika, mengedepankan nilai-nilai kebersamaan dan persaudaraan dalam berproduksi, dan menghindari kegiatan spekulatif dalam bertransaksi keuangan. Dengan menyediakan beragam produk serta layanan jasa perbankan yang beragam dengan skema keuangan yang lebih bervariatif, perbankan syariah menjadi alternatif sistem perbankan yang kredibel dan dapat dinikmati oleh seluruh golongan masyarakat Indonesia tanpa terkecuali.

Dalam konteks pengelolaan perekonomian makro, meluasnya penggunaan berbagai produk dan instrumen keuangan syariah akan dapat merekatkan hubungan antara sektor keuangan dengan sektor riil serta menciptakan harmonisasi di antara kedua sektor tersebut. Makin meluasnya penggunaan produk dan instrumen syariah di samping akan mendukung kegiatan keuangan dan bisnis masyarakat juga akan mengurangi transaksi-transaksi yang bersifat spekulatif, sehingga mendukung stabilitas sistem keuangan secara keseluruhan, yang pada gilirannya akan memberikan kontribusi yang signifikan terhadap pencapaian kestabilan harga jangka menengah-panjang (Latumaerissa, 2011).

Bank syariah didirikan dengan tujuan untuk mempromosikan dan mengembangkan penerapan prinsip-prinsip Islam, syariah dan tradisinya ke dalam transaksi keuangan dan perbankan serta bisnis lain yang terkait. Prinsip utama yang diikuti oleh bank Islami itu adalah: a) Larangan riba dalam berbagai bentuk transaksi; b) Melakukan kegiatan usaha dan perdagangan berdasarkan perolehan yang sah; c) Memberikan zakat. 
Sepanjang praktek perbankan konvensional tidak bertentangan dengan prinsipprinsip Islam, bank-bank Islam telah mengadopsi sistem dan prosedur perbankan yang ada. Bila terjadi pertentangan dengan prinsip-prinsip syariah, maka bank-bank Islam merencanakan dan menerapkan prosedur mereka sendiri guna menyesuaikan aktivitas perbankan mereka dengan prinsip-prinsip syariah Islam. Untuk itu Dewan Pengawas Syariah (DPS) berfungsi memberikan advis kepada perbankan Islam guna memastikan bahwa bank Islam tidak terlibat dalam unsur-unsur yang tidak disetujui oleh Islam.

Jika yang dimaksud dengan "bank" adalah istilah bagi suatu lembaga keuangan, maka istilah "bank" tidak disebutkan secara eksplisit dalam Al Qur'an. Tetapi jika yang dimaksud adalah sesuatu yang memiliki unsur-unsur seperti struktur, manajemen, fungsi, hak dan kewajiban, maka semua itu disebutkan dengan jelas, seperti zakat, shodaqah, ghanimah (rampasan perang), bai' (jual-beli), dayu (utang dagang), maal (harta) dan sebagainya, yang memiliki konotasi fungsi yang dilaksanakan oleh peran tertentu dalam kegiatan ekonomi. Lembaga-lembaga itu pada akhirnya bertindak sebagai individu yang dalam konteks fiqih disebut syaksyiyah al i'tibariyyah atau syaksiyyah al ma'nawiyyah (Mufti dan Sula, 2009).

Dalam artikel ini, penulis bermaksud ingin menjelaskan perbedaan antara bank syariah dan konvensional dari berbagai aspek. Dengan menggunakan metode analisis konten berdasarkan sumber-sumber sekunder yang kredibel dan kajian sebelumnya, penulis berharap agar perbedaan kedua konsep dan sistem bank ini semakin jelas dan dapat menjadi rujukan bagi kajian-kajian berikutnya.

\section{HASIL DAN PEMBAHASAN}

\section{Prinsip Perbankan Syariah}

Prinsip-prinsip syariah yang dilarang dalam operasional lembaga jasa keuangan syariah adalah kegiatan yang mengandung unsur-unsur sebagai berikut:

Maisir, Menurut bahasa maisir berarti gampang/mudah. Menurut istilah maisir berarti memperoleh keuntungan tanpa harus bekerja keras. Maisir sering dikenal dengan perjudian karena dalam praktik perjudian, seseorang dalam kondisi bisa untung atau bisa rugi. Sedangkan ketika tidak beruntung seseorang dapat mengalami kerugian yang sangat besar. Hameed (2009) mendefinisikan maisir sebagai judi, atau segala bentuk aktivitas bisnis di mana keuntungan keuangan diperoleh dari spekulasi atau 
dugaan/tebakan. Hal ini telah disebutkan dalam Al-Qur'an, Allah (SWT) dengan jelas melarang perjudian (Al-Baqarah, 2: 219 dan Al-Maidah, 5:93).

Gharar, Menurut bahasa gharar berarti pertaruhan. Menurut istilah gharar berarti sesuatu yang mengandung ketidakjelasan, pertaruhan, atau perjudian. Setiap transaksi yang masih belum jelas barangnya atau tidak berada dalam kuasanya alias di luar jangkauan termasuk jual beli gharar. Misalnya membeli burung di udara atau ikan dalam air atau membeli ternak yang masih dalam kandungan induknya termasuk dalam transaksi yang bersifat gharar. Pelarangan gharar karena memberikan efek negative dalam kehidupan karena gharar merupakan praktik pengambilan keuntungan secara bathil. Tidak ada bukti spesifik dari Al Qur'an yang berkonotasi dengan Gharar, namun Allah (SWT) menyebutkan bahwa seorang Muslim dilarang untuk memakan harta secara tidak adil atau dengan kebohongan dan tipu daya, kecuali itu merupakan perdagangan di antara kamu dengan persetujuan bersama. Ini tertulis pada surah dan ayat didalam AlQur'an yaitu Al-Baqarah, 2: 188; An-Nisa, 4: 29; Al-An'am, 6:152; Al-Mutaffifin, 83:1-3; Hud, 11: 85-86.

Riba, Makna harfiah dari kata riba adalah pertambahan, kelebihan, pertumbuhan, atau peningkatan, sedangkan menurut istilah teknis, riba berarti pengambilan tambahan dari harta pokok atau modal secara bathil baik dalam transaski jual beli maupun peminjam-meminjam. Para ulama sepakat bahwa hukumnya riba adalah haram (0JK, 2016). Larangan bunga (riba) dalam Islam merupakan jalan keluar untuk menghindari eksploitasi serta untuk menegakkan keadilan. Menurut Siddiqi (1981) alasan utama mengapa Islam menghapuskan 'bunga' adalah karena ianya suatu penindasan melalui eksploitasi. Selanjutnya, Mannan (1986) mengungkapkan bahwa bunga mencabut dasar atau fondasi kemanusiaan, menghindar dari saling menolong dan simpati, dan menciptakan keegoisan pada seseorang. Ramzan (1997) menambahkan bahwa alasan pelarangan bunga didasarkan pada kenyataan bahwa ia menjamin pengembalian yang pasti kepada pemodal sementara peminjam dibiarkan menanggung seluruh risiko bisnis. Islam ingin mempromosikan keadilan dan kesetaraan. Keadilan menuntut bahwa pemodal berbagi risiko dengan peminjam jika dia ingin mendapat untung. Khan (1988) menegaskan bahwa eliminasi riba akan memberikan dampak pada keadilan sosial. Oleh karena itu, wajib bagi setiap Muslim untuk menghilangkan unsur riba dari segala jenis 
transaksi. Peringatan tentang Riba dapat dilihat dari beberapa ayat Al-Qur'an seperti; AlImran, 3:130, Al-Baqarah, 2: 275-276; Al-Baqarah, 2: 278-279; Ar-Rum, 30: 39).

Haram, Haram yaitu objek (bendanya) dilarang dalam syariah, seperti perdaganagn jual beli hewan yang diharamkan dalam syariah, minuman keras dan lain-lain. Risywah, Risywah (suap) yaitu melakukan aktivitas yang berasal dari sumber penyuapan untuk mendapatkan sesuatu yang diinginkan. Bathil, Bathil (perbuatan yang salah), yaitu melakukan sesuatu aktivitas untuk mendapatkannya dengan cara yang tidak benar. Pada dasarnya semua aktivitas muamalah adalah boleh kecuali ada dalil yang melarangnya (OJK, 2016 dan Soemitra, 2014).

\section{Produk-produk Pembiayaan Bank Syariah dan Akad yang Digunakan.}

Dari sekian banyak produk pembiayaan bank syariah, tiga produk pembiayaan utama yang mendominasi portofolio pembiayaan bank syariah adalah pembiayaan modal kerja, pembiayaan investasi, dan pembiayaan aneka barang dan properti. Akadakad yang digunakan dalam aplikasi pembiayaan tersebut sangat bervariasi dari pola bagi hasil (mudharabah, musyarakah, dan musyarakah mutanaqisah), pola jual beli (murabahah, salam, dan istishna), atapun pola sewa (ijarah dan ijarah muntahiyah bit tamlik). (OJK, 2016).

Contoh-contoh produk pembiayaan bank syariah dan akad yang akan digunakan:

Tabel 3. Produk Pembiayaan dan Prinsip Bank Syariah

\begin{tabular}{|c|c|c|}
\hline No & Produk Pembiayaan & Prinsip \\
\hline 1 & Modal kerja & Mudharabah, Musyarakah, Murabahah, Salam \\
\hline 2 & Investasi & $\begin{array}{l}\text { Mudharabah, Musyarakah, Murabahah, Istishna, Ijaruh, } \\
\text { Ijarah Muntahiya Bi Tamlik }\end{array}$ \\
\hline 3 & $\begin{array}{l}\text { Pengadaan barang investasi, aneka } \\
\text { barang }\end{array}$ & $\begin{array}{l}\text { Mudharabah, Ijarah Muntahiya Bi Tamlik, Musyarakah } \\
\text { Mutanaqisah }\end{array}$ \\
\hline 4 & Perumahan, property & $\begin{array}{l}\text { Mudharabah, Ijarah Muntahiya Bi Tamlik, Musyarakah } \\
\text { Mutanaqisah }\end{array}$ \\
\hline 5 & Proyek & Mudharabah, Musyarakah \\
\hline 6 & Ekspor & Mudharabah, Musyarakah, Murabahah \\
\hline 7 & Produksi agribisnis/sejenis & Salam, Salam Paralel \\
\hline 8 & Manufaktur, konstruksi & Istishna, Istishna Paralel \\
\hline 9 & Penyertaan & Musyarakah \\
\hline 10 & Surat berharga & Mudharabah, Qardh \\
\hline 11 & Sewa beli & Ijarah, Muntahiya Bi Tamlik \\
\hline 12 & Akuisisi asset & Ijarah, Muntahiya Bi Tamlik \\
\hline
\end{tabular}




\section{Penilaian Waktu terhadap Uang (Time Value of Money) Sistem Perbankan Syariah (Pembiayaan dengan Bagi Hasil)}

Penyaluran dana dalam bank kovensional, kita kenal dengan istilah kredit atau pinjaman. Sedangkan dalam Bank Syariah untuk penyaluran dananya kita kenal dengan istilah pembiayaan. Jika dalam bank konvensional keuntungan bank diperoleh dari bunga yang dibebankan, maka dalam Bank Syariah tidak ada istilah bunga, tetapi Bank Syariah menerapkan sistem bagi hasil. Prinsip bagi hasil dalam Bank Syariah yang diterapkan dalam pembiayaan yaitu: 1) Al Mudharabah merupakan akad kerja sama antara dua pihak, dimana pihak pertama menyediakan seluruh modal dan pihak lain menjadi pengelola. Keuntungan dibagi menurut kesepakatan yang dituangkan dalam kontrak. Apabila rugi, maka akan ditanggung pemilik modal selama kerugian itu bukan akibat dari kelalaian sipengelola. Apabila kerugian diakibatkan kelalaian pengelola, maka sipengelolalah yang bertanggung jawab (Kasmir, 2010). 2) Al Murabahah merupakan kegiatan jual beli pada harga pokok dengan tambahan keuntungan yang disepakati. Dalam hal ini penjual harus terlebih dulu membertahukan harga pokok yang dibeli ditambah keuntungan yang diinginkannya. Sebagai contoh harga pokok barang perusahaan lezat Rp.1.000.000. Keuntungan yang diharapkan sebesar Rp.50.000, sehingga harga jualnya 1.050.000. (Kasmir, 2010).

Contoh Soal dan Penyelesaian: Mudharabah, Seorang pedagang yang memerlukan modal untuk berdagang dapat mengajukan permohonan untuk pembiyaan bagi hasil seperti mudharabah, dimana bank bertindak selaku shahibul maal (pihak pertama) dan nasabah selaku mudharib (pengelola). Caranya adalah dengan menghitung dulu perkiraan pendapatan yang akan diperoleh nasabah dari proyek yang bersangkutan. Misalnya, dari modal Rp 30.000.000,- perbulan diperoleh pendapatan Rp5.000.000,perbulan. Dari pendapatan ini harus disisihkan dahulu untuk tabungan pengembalian modal, misalnya Rp 2.000.000,-. Selebihnya dibagi antara bank dengan nasabah dengan kesepakatan dimuka, misalnya $60 \%$ untuk nasabah dan $40 \%$ untuk bank. (Antonio, 2016)

Mudharabah, yaitu cara perhitungan mudharabah (bagi hasil) Bank Syariah membagikan bagi hasilnya perbandingan nisbah (rasio) bank dan nasabah (45:55\%). Saldo rata- rata tabungan nasabah bank Syariah ini pada bulan Juni 2014 sebesar Rp. 200 juta. Pendapatan bersih bank yang akan dibagi hasilkan untuk nasabah tabungan sebesar 
Rp. 3 juta. Pak Ali (nasabah) mempunyai saldo rata-rata tabungan sebesar Rp. 1 juta pada Juni 2014.

Penyelesaian : Maka bagi hasil yang didapat Pak Ali bulan juni 2014 sbb:

$$
\begin{aligned}
& =\frac{R p 1 \text { Juta }}{R p 200 \text { Juta }} \times 55 \% \text { x Rp } 3 \text { juta } \\
& =\frac{1}{200} \times 55 \% \times \text { Rp } 3 \text { juta } \\
& =\operatorname{Rp~8.250,-~}
\end{aligned}
$$

Contoh Soal dan Penyelesaian Al Murabahah (Margin): Misalkan seorang nasabah ingin memiliki sebuah sepeda motor. Ia datang ke bank syariah dan memohon agar bank membelikannya. Setelah diteliti dan dinyatakan dapat diberikan, bank membelikan sepeda motor tersebut dan diberikan kepada nasabah. Jika harga sepeda motor tersebut Rp 12 juta dan bank ingin mendapat keuntungan Rp 2.400.000,- selama 2 tahun, harga yang ditetapkan kepada nasabah seharga $\mathrm{Rp} 14.400 .000$,- nasabah dapat mencicil pembayaran tersebut sebesar Rp 600.000,- perbulan.

Musyarakah (fee), Musyarakah merupakan akad kerja sama antara dua pihak atau lebih untuk melakukan usaha tertentu. Masing-masing pihak memberikan dana atau amal dengan kesepakatan bahwa keuntungan atau resiko akan ditanggung bersama sesuai dengan kesepakatan. Dalam prakteknya perbankan Al Musyarakah diaplikasikan dalam hal pembiayaan proyek. (Kasmir, 2010).

Contoh Soal dan Penyelesaian Musyarakah (fee): Pak Usman adalah seorang pengusaha yang akan melaksanakan suatu proyek. Usaha tersebut membutuhkan modal sejumlah Rp 100.000.000,- ternyata, setelah dihitung, Pak Usman hanya memiliki Rp 50.000.000,- atau 50\% dari modal yang diperlukan. Pak Usman kemudian datang ke sebuah bank syariah untuk mengajukan pembiayaan dengan skema musyarakah. Dalam hal ini, kebutuhan terhadap modal sejumlah $\mathrm{Rp}$ 100.000.000,- dipenuhi 50\% dari nasabah dan $50 \%$ dari bank. Setelah proyek selesai, nasabah mengembalikan dana tersebut bersama bagi hasil yang telah disepakati untuk bank. Seandainya keuntungan dari proyek tersebut adalah Rp 20.000.000,- dan nisbah atau porsi bagi hasil yang disepakati adalah 50:50 (50\% untuk nasabah dan 50\% untuk bank), pada akhir proyek Pak Usman harus mengembalikan dana sebesar Rp 50.000.000,- (dana pinjaman dari bank) ditambah Rp 10.000.000,- (50\% dari keuntungan untuk bank) (Antonio, 2016). 


\section{Perbedaan Antara Bunga dan Bagi Hasil}

Sekali lagi, Islam mendorong praktik bagi hasil serta mengharamkan riba. Keduanya sama-sama memberi keuntungan bagi pemilik dana, namun keduanya mempunyai perbedaan yang sangat nyata. Perbedaan itu dapat dijelaskan dalam tabel berikut.

Tabel 4. Perbedaan Antara Bunga dan Bagi Hasil

\begin{tabular}{|l|l|}
\hline Bunga & Bagi Hasil \\
$\begin{array}{l}\text { a. Penentuan bunga pada waktu akad dengan } \\
\text { asumsi harus selalu untung. }\end{array}$ & $\begin{array}{l}\text { a.Penentuan besarnya rasio/nisbah bagi hasil } \\
\text { dibuat pada waktu akad dengan berpedoman pada } \\
\text { kemungkinan untung rugi }\end{array}$ \\
\begin{tabular}{l|l|} 
b. Besarnya persentase berdasarkan pada jumlah \\
uang (modal) yang dipinjamkan
\end{tabular} & $\begin{array}{l}\text { b. Besarnya rasio bagi hasil berdasarkan pada } \\
\text { jumlah keuntungan yang diperoleh }\end{array}$ \\
\hline $\begin{array}{l}\text { c. Pembayaran bunga tetap seperti yang dijanjikan } \\
\text { tanpa pertimbangan apakah proyek yang } \\
\text { dijalankan oleh pihak nasabah untung atau rugi }\end{array}$ & $\begin{array}{l}\text { c. Bagi hasil bergantung pada keuntungan proyek } \\
\text { ditanggung bersama oleh kedua belah pihak. }\end{array}$ \\
\hline $\begin{array}{l}\text { d. Jumlah pembayaran bunga tidak meningkat } \\
\text { sekalipun jumlah keuntungan berlipat atau } \\
\text { keadaan ekonomi sedang "booming" }\end{array}$ & $\begin{array}{l}\text { d. Jumlah pembagian laba meningkat sesuai } \\
\text { dengan peningkatan jumlah pendapatan. }\end{array}$ \\
\hline $\begin{array}{l}\text { e. Eksistensi bunga diragukan (kalau tidak } \\
\text { dikecam) oleh semua agama, termasuk Islam. }\end{array}$ & e. Tidak ada yang meragukan keabsahan bagi hasil. \\
\hline
\end{tabular}
Sumber: Antonio (2016: 61)

\section{Konsep Uang dalam Perspektif Islam}

Dalam ekonomi Islam, konsep uang sangat jelas dan tegas bahwa uang adalah uang bukan capital. Sebaliknya konsep uang yang dikemukakan ekonomi konvensional tidak jelas. Sering kali istilah uang dalam perspektif ekonomi konvensional diartikan secara bolak-balik (interchangeability), yaitu uang sebagai uang dan uang sebagai kapital.

Perbedaan lain dalam ekonomi Islam, bahwa uang adalah sesuatu yang bersifat flow concept dan capital adalah sesuatu yang bersifat stock concept. Sedangkan dalam ekonomi konvensional terdapat beberapa pengertian. Frederic S Mishkin, misalnya mengemukakan konsep Irving Fisher yang menyatakan bahwa:

$$
\begin{aligned}
& \mathrm{MV} \quad=\mathrm{PT} \\
& \mathrm{M} \quad=\text { Jumlah Uang } \\
& \mathrm{V}=\text { Tingkat perputaran uang } \\
& \mathrm{P}=\text { Tingkat harga barang } \\
& \mathrm{T}=\text { Jumlah barang yang diperdagangkan }
\end{aligned}
$$


Dari persamaan di atas dapat diketahui bahwa semakin cepat perputaran uang (V), maka semakin besar income yang diperoleh. Persamaan ini juga berarti bahwa uang adalah flow concept. Fisher juga mengatakan bahwa: sama sekali tidak ada korelasi antara kebutuhan memegang uang (demand for holding money) dengan tingkat suku bunga. Konsep Fisher ini hampir sama dengan konsep yang ada dalam ekonomi Islam, bahwa uang adalah flow concept bukan stock concept.

\section{Perbedaan Konsep Uang Menurut Islam dan Konvensional}

Konsep uang dalam ekonomi Islam berbeda dengan konsep uang dalam ekonomi konvensional. Dalam ekonomi Islam, konsep uang sangat jelas dan tegas bahwa uang adalah uang bukan modal (capital). Pandangan ekonomi konvensional uang diartikan secara bolak-balik (interchange ability) yaitu uang sebagai uang dan uang sebagai modal (capital).

Tabel 5. Perbedaan konsep uang menurut Islam dan Konvensional

\section{KONSEP ISLAM}

Uang tidak identik dengan modal

Uang adalah public goods

Modal adalah private goods

Uang adalah flow concept

Modal adalah stock concept

\section{KONSEP KONVENSIONAL}

Uang sering kali diidentikkan dengan modal Uang (modal) adalah private goods Uang (modal) adalah flow concept bagi Fisher Uang (modal) adalah stock concept bagi Cambridge School

Untuk lebih jelasnya, konsep private dan public goods masing-masing dapat diilustrasikan dengan mobil dan jalan tol. Mobil adalah private goods (capital) dan jalan tol adalah public good (money). Apabila mobil tersebut menggunakan jalan tol, baru kita dapat menikmati jalan tol. Namun, apabila mobil tersebut tidak menggunakan jalan tol, maka kita tidak akan menikmati jalan tol tersebut.

Dengan kata lain, jika dan hanya uang diinvestasikan dalam proses produksi, maka kita baru akan mendapatkan lebih banyak uang. Sedangkan karena dalam konsep konvensional uang dan capital dapat menjadi private goods, maka bagi mereka jika mobil diparkir dalam garasi ataupun digunakan dijalan tol, mereka tetap akan menikmati manfaat dari jalan tol tersebut. Apakah uang diinvestasikan pada proses produksi atau tidak, mereka tetap harus mendapat lebih banyak uang. Di sinilah letak keanehan teori bunga (interest theory) yang dikemukakan para ekonom konvensional (Soemitra, 2014).

\section{Perbedaan Konsep dan Produk Bank Syariah dan Bank Konvensional}


Konsep Dasar Bank Syariah, Bank Islam atau di Indonesia lazim disebut sebagai Bank Syariah, merupakan lembaga keuangan yang berfungsi memperlancar mekanisme ekonomi di sektor riil melalui aktivitas kegiatan usaha (investasi, jual beli, atau lainnya) berdasakan prinsip syariah, yaitu aturan perjanjian berdasarkan hukum Islam antara bank dan pihak lain untuk penyimpanan dana dan atau pembiayaan kegiatan usaha, atau kegiatan lainnya yang dinyatakan sesuai dengan nilai-nilai syariah. Nilai-nilai makro yang dimaskud adalah keadilan, maslahah, sistem zakat, bebas dari bunga (riba), bebas dari kegiatan spekulatif yang nonproduktif seperti perjudian (maysir), bebas dari hal-hal yang tidak jelas dan meragukan (gharar), bebas dari hal-hal yang rusak atau tidak sah (bathil), dan penggunaan uang sebagai alat tukar. Sedangkan nilai-nilai mikro yang harus dimiliki oleh pelaku perbankan syariah adalah sifat-sifat mulia yang dicontohkan oleh Rasulullah SAW, yaitu jujur (shiddiq), dipercaya (amanah), menyampaikan (tabligh), dan cerdas (fathonah). Selain itu, dimensi keberhasilan bank syariah meliputi keberhasilan dunia dan akhirat (long term oriented) yang sangat meperhatikan kebersihan sumber, kebenaran proses, dan kemanfaatan hasil (OJK, 2016).

Kelembagaan Perbankan Syariah, Perbankan di Indonesia terdiri dari dua jenis yaitu bank umum dan bank perkreditan rakyat (BPR). Kedua jenis bank tersebut beroperasi melaksanakan kegiatan konvensional dan syariah. Secara umum terdapat bentuk usaha bank syariah terdiri dari bank umum syariah (BUS) dan bank pembiayaan rakyat syariah (OJK, 2016).

Secara kelembagaan bank syariah di Indonesia dalam bentuk yaitu bank umum syariah/BUS (Full Fledged Islamic Bank) dan unik usaha syariah/UUS (bank konvensional yang membuka cabang syariah) dan office channeling (gerai syariah di kantor bank konvensional) (Ascarya, 2012). Pembagian tersebut serupa dengan bank konvensional, dan sebagaimana halnya di atur dalam undang-undang perbankan. Undang-undang perbankan juga mewajibkan setiap pihak yang melakukan kegiatan penghimpunan dana masyarakat dalam bentuk simpanan atau investasi berdasarkan prinsip syariah harus terlebih dahulu mendapat izin OJK.

Perbandingan antara bank syariah dan bank konvensional disajikan dalam tabel di bawah ini:

Tabel 2. Perbandingan Bank Islam dan Konvensional 
Melakukan investasi-investasi yang halal saja

Berdasarkan prinsip bagi hasil, jual beli atau sewa

Berorientasi keuntungan dan falah (kemenangan abadi)

Hubungan dengan nasabah dalam bentuk kemitraan

Perhimpunan dan penyaluran dana harus sesuai dengan fatwa Dewan Pengawas Syariah
Investasi yang halal dan haram

Memakai perangkat bunga

Berorientasi keuntungan

Hubungan dengan nasabah dalam bentuk hubungan debitor-debitor. Tidak terdapat dewan sejenis

Sumber: Mufti dan Sula (2009: 62)

\section{Perbedaan Antara Investasi dan Membungakan Uang}

Ada dua perbedaan mendasar antara investasi dan membungakan uang. Perbedaan tersebut dapat ditelaah dari definisi hingga makna masing-masing: a) Investasi adalah kegiatan usaha yang mengandung resiko karena berhadapan dengan unsur ketidakpastian. Dengan demikian, perolehan kembaliannya (return) tidak pasti dan tidak tetap; b) Membungakan uang adalah kegiatan usaha yang kurang mengandung resiko karena perolehan kembaliannya berupa bunga yang relatif pasti dan tetap.

Islam mendorong masyarakat ke arah usaha nyata dan produktif. Islam mendorong seluruh masyarakat untuk melakukan investasi dan melarang membungakan uang. Sesuai dengan definisi diatas, menyimpan uang di bank Islam termasuk kategori kegiatan investasi karena perolehan kembaliannya (return) dari waktu ke waktu tidak pasti dan tidak tetap. Besar kecilnya perolehan kembali itu bergantung pada hasil usaha yang benar-benar terjadi dan dilakukan Bank sebagai mudharib atau pengelola dana.

Dengan demikian, Bank Islam tidak dapat sekedar menyalurkan uang. Bank Islam harus terus berupaya meningkatkan kembalian atau Return Of Investment sehingga lebih menarik dan memberi kepercayaan bagi pemilik dana.

Dalam pandangan Islam, uang adalah flow concept, sehingga harus selalu berputar dalam perekeonomian. Semakin cepat uang berputar dalam perekonomian, maka akan semakin tinggi tingkat pendapatan masyarakat, dan semakin baik perekonomian (Arifin, 2009).

\section{Laporan Keuangan Bank Konvensional dan Bank Syariah}

Laporan Keuangan (financial statements) adalah laporan berkala yang menggambarkan (ihktisar) tentang posisi keuangan suatu badan/perusahaan pada suatu 
saat tertentu, hasil usaha selama periode tertentu dan perubahan yang telah terjadi atas posisi keuangan tadi, sekaligus untuk keperluan ke dalam dan ke luar perusahaan menunjukkan kekayaan, hasil yang dicapai dan perubahan posisi keuangan perusahaan.

Laporan keuangan bank konvensional secara garis besar dibedakan menjadi empat macam yaitu Pertama laporan keuangan yang menggambarkan tentang posisi keuangan perusahaan tersaji dalam neraca. Kedua laporan keuangan yang menggambarkan hasil usaha (kinerja) perusahaan tersaji dalam laporan laba rugi. Ketiga laporan keuangan yang menggambarkan tentang perubahan yang terja di atas posisi keuangan tersaji dalam laporan arus kas.

Keempat laporan keuangan yang menggambarkan tentang perubahan modal terjadi dalam laporan perubahan modal. Dari keempat laporan tersebut dapat diringkas lagi menjadi dua macam, yaitu laporan neraca dan laporan laba rugi saja. Hal ini karena laporan perubahan modal dan laporan aliran kas pada akhirnya akan diikhtisarkan dalam laporan neraca atau laporan laba rugi.

Adapun komponen laporan keuangan bank konvensional ada 5 yaitu: Menurut Standar Akuntansi (SAK) yang dikeluarkan Ikatan Akuntan Indonesia (IAI), laporan keuangan yang lengkap terdiri dari komponen berikut ini (Irham, 2018): a) Neraca (Balance Sheet / Statement of Financial Position / Financial Position Statement); b) Laporan Laba Rugi (Income Statement / Profit \& Loss Statement / Revenue and Expense Statement); c) Laporan Arus Kas (Statement of Cash Flow / Cash Flow Statement); c) Laporan Perubahan Ekuitas (Statement of Changes and Equity); d) Catatan atas Laporan Keuangan (Notes to Financial Statement)

Laporan Keuangan Bank Syariah, Adapun laporan keuangan bank syariah ada 7 yaitu: Laporan keuangan bank syariah menggunakan accrual basis dan perhitungan bagi hasil menggunakan cash basis. 
Laporan Rekonsiliasi Bagi Hasil:

\begin{tabular}{|ll|}
\hline a. & Laporan Posisi Keuangan/ Neraca \\
b. & Laporan laba rugi \\
c. & Laporan perubahan equity \\
d. & Laporan arus kas \\
\hline
\end{tabular}

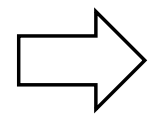

Laporan sebagai investor dan manajer investasi

g. Laporan perubahan Investasi Terikat

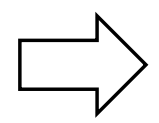

Laporan sebagai agen (manager investasi)

\begin{tabular}{|ll|}
\hline e. & Laporan sumber dan penggunaan dana \\
& zakat \\
f. & Laporan sumber dan penggunaan dana \\
& kebajikan
\end{tabular}

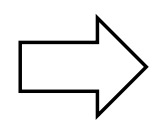

Laporan pemegang amanah / fungsi sosial

\section{SIMPULAN}

Perbankan konvensional dan syariah ada persamaan dan perbedaan. Dalam jangka pendek perbankan syariah nasional lebih diarahkan pada pelayana pasar domestik yang potensinya masih sangat besar. Perbankan syariah nasional harus sanggup untuk menjadi pemain domestik akan tetapi memiliki kualitas layanan dan kinerja bersifat Internasional.

Pada akhirnya sistem perbankan syariah yang ingin diwujudkan oleh Otoritas Jasa Keuangan (OJK) adalah perbankan syariah yang modern, yang bersifat universal, terbuka bagi seluruh masyarakat Indonesia tanpa terkecuali. Sebuah sistem perbankan yang menghadirkan bentuk-bentuk aplikatif dari konsep ekonomi syariah yang dirumuskan secara bijaksana, dalam konteks kekinian permasalah yang sedang dihadapi oleh bangsa Indonesia dan tetap memperhatikan kondisi sosial kultural di dalam bangsa ini. Hanya dengan cara demikian, upaya pengembangan sistem perbankan syariah akan senantiasa dilihat dan diterima segenap masyarakat Indonesia sebagai bagian dari solusi atas berbagai permasalahan dalam negeri.

\section{DAFTAR PUSTAKA}

Antonio, M.S. (2016), Bank Syariah, Dari Teori Ke Praktek, Cetakan ke 26, Gema Insani, Jakarta. Arifin, Z. (2009), Dasar-dasar Manajemen Bank Syariah, Cetakan ke 7, Azkia Publisher, Jakarta. Ascarya (2012), Akad dan Produk Bank Syariah, Cetakan ke 4, Raja Grafindo Persada, Jakarta. Hameed, S. (2009), Accounting and Auditing for Islamic Financial Institutions, Kuala Lumpur: International Islamic University Malaysia

Irham, (2018), Pengantar Manajemen Keuangan, Bandung: Alfabeta

Kasmir (2010), Bank dan Lembaga Keuangan Lainnya, Edisi Revisi, Rajawali Pers, Jakarta.

Khan, S.R. (1988), "Henry George and an alternative Islamic land tenure system", Economic Development and Cultural Change, Vol. 36 No. 4, pp. 721-39. 
Latumaerissa, J.R. (2011), Bank dan Lembaga Keuangan Lain, Salemba Empat, Jakarta.

Mannan, M.A. (1986), Islamic Economics: Theory and Practice, Hodder and Stoughton, Cambridge.

Mufti A. dan Sula, M.S. (2004), Amanah Bagi Bangsa Ekonomi Berbasis Syariah, Edisi Kedua Majelis Ulama Indonesia (MUI), Jakarta.

Otoritas Jasa Keuangan (OJK) (2016), Industri Jasa Keuangan Syariah, Seri Literasi Keuangan Perguruan Tinggi, Jakarta.

Otoritas Jasa Keuangan (OJK) (2019), Snapshot Perbankan Syariah Indonesia Tahun 2019. https://www.ojk.go.id/id/kanal/syariah/berita-dankegiatan/publikasi/Documents/Pages/Snapshot-Perbankan-Syariah-Indonesia-Maret2019/Snapshot\%20Perbankan\%20Syariah\%20Maret\%202019.pdf

Ramzan, A.K. (1997), "Partnership financing of microenterprises", International Journal of Social Economics, Vol. 24 No. 12, pp. 1470-80.

Siddiqi, M.N. (1981), "Muslim economic thinking: a survey of contemporary literature”, in Ahmad, K. (Ed.), Studies in Islamic Economics, The Islamic Foundation, Markfield, pp. 191-269.

Soemitra, A. (2014), Bank dan Lembaga Keuangan Syariah, cetakan ke 4, Kencana, Jakarta. 